\title{
Seasonality and Climatic Factors Affect Diversity and Distribution of Arthropods Around Wetlands
}

\author{
Waqar Majeed ${ }^{1}$, Naureen Rana ${ }^{1}$, Elmo Borges de Azevedo Koch ${ }^{2 *}$ and Shahla Nargis ${ }^{1}$ \\ ${ }^{1}$ Department of Zoology, Wildlife and Fisheries, University of Agriculture Faisalabad, \\ Pakistan \\ ${ }^{2}$ Myrmecology Laboratory, Cocoa Research Center, CEPEC/CEPLAC, Ilhéus, Brazil
}

\section{A B S T R A C T}

The diversity and distribution of arthropods associated with seasons and environmental variables in two different wetlands sites was estimated and study was performed on monthly basis for a whole year. The arthropods were collected by sweep net, direct hand picking, forceps. For each sampling day in each month, 20 sweeps were randomly taken in each block. The insects at rest or on shrubs were manually collected. Overall, 5867 individuals were recorded pertaining to 152 species. Among the arthropods collected from two fields, number of the order Diptera was most diverse followed by those of Coleoptera, Hymenoptera, Hemiptera, Orthoptera, Lepidoptera, Araneae and Neuroptera. The number of arthropod species differed between localities and between the studied seasons. The arthropod composition varied significantly according to the sampled sites and according to the seasons studied. Temperature was positively correlated to diversity while humidity was negatively correlated to diversity and abundance. Results might be beneficial in developing the strategy for natural biological control. This can only be achieved by coordinated planning and conservation measures among sites.

\begin{tabular}{l} 
Article Information \\
Received 12 January 2020 \\
Revised 20 April 2020 \\
Accepted 13 May 2020 \\
Available online 04 September 2020 \\
Authors' Contribution \\
\hline WM and NR conceived and designed \\
the experiments. WM and SN \\
performed the experiments. WM, \\
EBAK and SN analyzed the data. WM \\
and EBAK wrote the manuscript. \\
Key words \\
Diversity, Environmental variables, \\
Wetlands, Ecological indicators, \\
Pakistan
\end{tabular}

\section{INTRODUCTION}

$\mathrm{W}$ e all are well aware that climate change is occurring (Houghton et al., 2001), and these may affect the diversity and distribution of various organisms (Bale et al., 2002). Population dynamics is dominant challenge to ecology to drive population cycle, response of species to ecological variation can interact with density dependent feedback processes (Crozier, 2004; Zamani et al., 2006; Savage et al., 2004; Amarasekare and Sifuentes, 2012). Negative feedback mechanism is delayed due to the intricacies in life cycles (e.g. intraspecific competitions), which provokes the series in population cycles (Murdoch et al., 2003; Amarasekare and Coutinho, 2014; Nisbet and Gurney, 1983; Nisbet, 1997).

Arthropods play consequential function in ecosystems service, including; predatory role, pollination processes, nutrient recycling, parasitoid behavior and in the sustainability of the ecosystem. Alteration in insect biodiversity and richness has threats of changing the services being provided by these tiny creatures (Hillstrom and Lindroth, 2008).

Diversity and distribution of fauna is directly and

\footnotetext{
Corresponding author: elmoborges@gmail.com 0030-9923/2020/0006-2135 \$9.00/0 Copyright 2020 Zoological Society of Pakistan
}

indirectly affected by abiotic variation. It is noteworthy that, species are declining with regards to amend in environmental factors. Reproduction, development, interaction and historical traits (Dannon et al., 2010; Englund et al., 2011; Lang et al., 2011) and conservation of species is mainly impacted by direct effect of abiotic factors (Hou and Weng, 2010; Jandricic et al., 2010; Urbaneja et al., 2001; Castillo et al., 2006; De Conti et al., 2010; Nishikawa et al., 2010; Morgan et al., 2001; Bommiredyy et al., 2004; Medeiros et al., 2003; Ragland and Kingsolver, 2008; Parajulee, 2006; Matadha et al., 2004; Huang et al., 2008; Ulmer et al., 2006). Indirect effects of environmental variation also putting the values down of arthropods abundance and distribution. Considerate as the atypical environment, meaning i.e. climate change, influence the density of a specific population by exerting direct and indirect effects (Bale et al., 2002; McMahon et al., 2011; Deutsch et al., 2008; Sheldon et al., 2013; Root et al., 2003; Kingsolver et al., 2011). Present study site has been chosen to expound the mechanism that drive species, because seasonal and climatic variation are operating the ecosystem as in changing the sequences of fauna and less known diversity and abundance of arthropods.

Climatic variations are giant dilemma in different ecosystems; as seasonal extremes alter the diversity and abundance of arthropods in any territory. The common 
aspects that affect species diversity in any ecosystem include habitat structure climate and biogeographical dynamics (Dossey, 2010). Wet territories have significant role in the strengthen of ecosystem, and in the amelioration of fauna. Arthropods play eminent role in pollination (Berenbaum et al., 2006; Thompson and McLachlan, 2007), biological control agents of pest (Choate and Drummond, 2011). Arthropods are effective indicator of ecological variations due to their miscellaneous natural features and necessities (Hall and Castner, 2000; Clarke et al., 2008; Jaganmohan et al., 2012).

Alterations in seasons and climate have a great influence on insects and plants association at various aspects; either directly, by change in physiological aspects or indirectly by morphological changes endured by hosts plant (Morrison and Morecroft, 2006) along with the thruway of abundance, biodiversity, evenness and richness (Thuiller et al., 2005). Diversity of the arthropods is influenced by the season rather than the age of the plantation as well as seasonality have a great impact on diversity, abundance, richness and evenness of arthropod fauna (Liu et al., 2013). Seasons prevail different substantial distributional patterns of terrestrial arthropod community (Doblas-Miranda et al., 2007). Some studies demonstrated the impact of shrubs age on temporal-spatial distribution of biodiversity of arthropods community at various microenvironment in different season (Whitford, 2000).

Recent regional reports and trends in biomonitoring suggest that insects are experiencing a multicontinental crisis that is apparent as reductions in abundance, diversity, and biomass (Forister et al., 2019; Wagner, 2018; Dirzo et al., 2014; Janzen and Hallwachs, 2019; Sánchez-Bayo and Wyckhuys, 2019). Further work needs to be done in the study area by expanding the scope and duration of the study area and also, by employing different sampling techniques. Motivated by a distinguishing pattern observed in the dynamics of population, we develop a hypothesis: Population dynamics/ diversity and distribution can be directly and indirectly influence by seasonality and abiotic factors. This study focuses on the diversity of distribution of arthropods population in accordance with seasonality and climatic variations.

\section{MATERIALS AND METHODS}

\section{Sampling area}

The research area was selected from two different water bodies of Faisalabad, Pakistan: Lake and Canal territories (Table I). Faisalabad is present at a height of $182.88 \mathrm{~m}$ above ocean level, having the latitude of $30^{\circ}$ to $31.5^{\circ} \mathrm{N}$ and at longitude of $73^{\circ}$ to $74^{\circ} \mathrm{E}$ (GOP, 2016).
Sampling and identification

The sampling was made from the selected fields for one year (four seasons, monthly from each territory between January to December 2018. The foliage fauna was collected from the fields (Lake and Canal) territory for 02 hours from 08:00-10:00 hr. The arthropods were collected by Sweep net, direct hand picking, forceps. For sampling day in each month, 20 sweeps were randomly taken in each block (Quadrate) while insects at rest or on shrubs and soil surface were manually collected.

After collection specimens were put in killing jars. Identification were made based on microscopes observations, following taxonomic keys (Borror and DeLong, 2005; Triplehorn and Johnson, 2005; Rafi et al., 2005). Subsequently, recognized specimens were specifically organized in the tabular arrangement as specified by their taxonomy e.g. order, family, genus, species on the base of their morphological characteristics. During the whole trial temperature and humidity were also noted of the sampling day (these variables were noted before the start and at the end of sampling and were averaged/mean) for the correlation analysis with species diversity.

\section{Statistical analysis}

Diversity related various issues were calculated according to Shannon's Diversity Index (Shannon, 1948). Thereafter, all the observed specimens were arranged in table form according to their morphological and taxonomic characters. Variations in arthropod richness according to seasons and localities were evaluated using two-way ANOVA, followed by Tukey's pairwise multiple comparison tests. Variation in species composition was evaluated using a Permutational Multivariate Analysis of Variance (PERMANOVA; Anderson, 2001). The similarity distance was calculated by the Bray-Curtis index. Statistical significance was obtained through comparisons with a null model (4999 permutations of the original matrix). To illustrate these possible differences in species composition was conducted a non-metric multidimensional scaling (NMDS). These analyses were performed in R software v. 3.5.0 (R Development Core Team, 2018) using vegan 2.3-4 package (Oksanen et $a l ., 2015)$. We graphically analyzed the residuals for the assumptions of the tests performed, including the normality of errors and the homogeneity of variances. All tests were analyzed at the level of significance $\alpha=0.05$. Additionally, to sustain the reliability and to decrease uncertainty, data from the four seasons were also combined and used to present part of the results. The following metrics were used to estimate diversity: Shannon's diversity index, species richness, species dominance, species evenness and community dominance (Shannon, 1948; Magurran, 1988). 
Table I. Characterization of the two different water bodies studied in Faisalabad, Pakistan.

\begin{tabular}{lll}
\hline Information & Canal & Lake \\
\hline Coordinates & $31.4504^{\circ} \mathrm{N}, 73.1350^{\circ} \mathrm{E}$ & $31.4504^{\circ} \mathrm{N}, 73.1350^{\circ} \mathrm{E}$ \\
Extension & 5 hectares & 5 hectares \\
Vegetation & $\begin{array}{l}\text { Agriculture crops, grassland, plantation (small } \\
\text { and large) }\end{array}$ & Grassland, herbs and shrubs \\
Soil characteristics & $\begin{array}{l}\text { Silt and sandy loam, pH 8-9, decaying organic } \\
\text { matter 55-65 \% }\end{array}$ & $\begin{array}{l}\text { Silt and sandy loam, deep and dark, } \\
\text { decaying organic matter 55-65 \% }\end{array}$ \\
$\begin{array}{l}\text { Distance from water bodies (Area in } \\
\text { which sampling is done) }\end{array}$ & $100-1000 \mathrm{~m}$ & $100-1000 \mathrm{~m}$ \\
Distance between water bodies & 12 Kilometers &
\end{tabular}

\section{RESULTS}

Overall, 5867 specimens were documented and resulted that abundance as well as species diversity was maximum for Lake $61.63 \%(n=3616)$, while minimum was recorded for canal $38.37 \%(\mathrm{n}=2251)$. Whole data pertaining to 2 classes, 8 orders, 61 families, 91 genera, 114 species and 2 classes, 7 orders, 42 families, 61 genera, 77 species from lake and canal respectively (Supplementary Table I). From Lake, the highest abundance was recorded for Tanytarsus spp. $17.56 \%(\mathrm{n}=649)$ followed by Exitianus indicus $6.66 \%(\mathrm{n}=241)$ and from canal maximum was recorded for Musca domestica $8.22 \%(\mathrm{n}=185)$ followed by Lucilia sericata $6.09 \%(\mathrm{n}=137)$, while certain species had less abundance or found only at single site. At the order level, Diptera remained extraordinary $46.47 \%$ and $37.39 \%$ from lake and canal respectively, followed by other orders in (Fig. 1). Variations in species abundance were observed between different seasons for both sites. It was noted that species showed significant variation among different seasons viz. From lake fields (spring, summer, autumn, winter) seasons abundance was noted $36.89 \%$, $20.46 \%, 28.29 \%, 14.35 \%$ respectively. From canal fields, abundance was documented as for all seasons $34.87 \%$, $20.12 \%, 29.41 \%, 15.59 \%$ respectively.

The temperature was significant and positively correlated with the diversity of arthropods (Lake territory: $\mathrm{r}=0.502, p<0.05$; Canal territory: $\mathrm{r}=0.481, p<0.05$ ) and humidity was significant negatively correlated with diversity (Lake territory: $\mathrm{r}=-0.334, p<0.01$; Canal territory: $\mathrm{r}=0.481, p<0.01$ ) (Table II).

From Lake species abundance varies 519 (Winter) from 1334 (Spring), while in Canal abundance varies 351 (winter) from 785 (spring) (Table III). Diversity (H'): 3.62 was the maximum diversity recorded from the Lake territory, whereas, from Canal the maximum value was 3.55 in summer for both territories. Dominance (D): dominance was recorded maximum for spring season of Lake 0.088 and for Canal maximum 0.066 was documented in winter season. Evenness (J): Highest evenness was recorded highest 0.778 from Canal fields and maximum for Lake fields 0.616. Richness S: Richness was noted maximum 10.44 and minimum 7.651 for spring season of Lake and Canal respectively. Community dominance: in the spring season of both territories $\mathrm{CD} \%$ was recorded maximum. Other diversity indices were also noted (Table III).

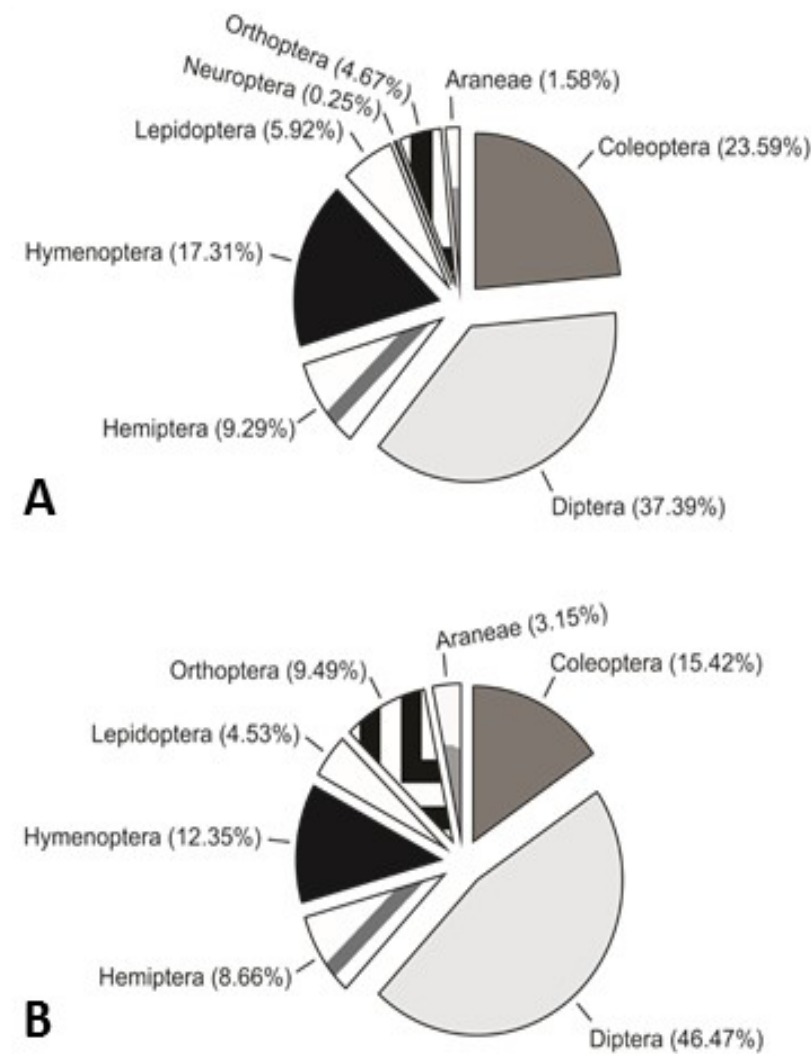

Fig. 1. Diversity and abundance of insect fauna in lake (A) and canal $(\mathrm{B})$ territories. 
Table II. Correlation analysis of species with abiotic factors (temperature, humidity). *p $<0.05, * * p<0.01, * * * p<$ 0.001, n.s= no significant difference.

\begin{tabular}{|c|c|c|c|c|c|c|}
\hline \multirow[t]{2}{*}{ Factors } & \multicolumn{3}{|c|}{ Lake } & \multicolumn{3}{|c|}{ Canal } \\
\hline & Abundance & Temperature & Humidity & Abundance & Temperature & Humidity \\
\hline Abundance & 1 & $0.502 *$ & $-0.334^{\mathrm{NS}}$ & 1 & $0.481 *$ & $-0.607 * *$ \\
\hline Temperature & & 1 & $-0.765^{* *}$ & & 1 & $-0.736^{* *}$ \\
\hline Humidity & & & 1 & & & 1 \\
\hline
\end{tabular}

Table III. Diversity, abundance, dominance, evenness and richness of species recorded in the two water bodies (canal and lake) studied in Faisalabad, Punjab, Pakistan.

\begin{tabular}{|c|c|c|c|c|c|c|c|c|}
\hline \multirow[t]{2}{*}{ Diversity factors } & \multicolumn{4}{|c|}{ Lake } & \multicolumn{4}{|c|}{ Canal } \\
\hline & Spring & Summer & Autumn & Winter & Spring & Summer & Autumn & Winter \\
\hline Individuals & 1334 & 740 & 1023 & 519 & 785 & 453 & 662 & 351 \\
\hline Taxa richness $\mathrm{S}$ & 79 & 72 & 40 & 30 & 52 & 45 & 36 & 31 \\
\hline Dominance D & 0.088 & 0.060 & 0.058 & 0.051 & 0.063 & 0035 & 0.064 & 0.066 \\
\hline Simpson 1-D & 0.911 & 0.939 & 0.9414 & 0.938 & 0.936 & 0.964 & 0.935 & 0.933 \\
\hline Community dominance $\%$ & 338.94 & 159.08 & 162.38 & 61.29 & 128.30 & 46.18 & 107.78 & 69.69 \\
\hline Diversity H & 3.3 & 3.62 & 3.206 & 3.007 & 3.234 & 3.556 & 3.097 & 3.042 \\
\hline Evenness e $\wedge \mathrm{H} / \mathrm{S}$ & 0.343 & 0.518 & 0.616 & 0.674 & 0.488 & 0.778 & 0.614 & 0.675 \\
\hline Brillouin & 3.189 & 3.445 & 3.12 & 2.894 & 3.11 & 3.369 & 2.987 & 2.881 \\
\hline Menhinick & 2.16 & 2.647 & 1.251 & 1.317 & 1.856 & 2.114 & 1.399 & 1.655 \\
\hline Magarlef & 10.84 & 10.75 & 5.6277 & 4.639 & 7.651 & 7.194 & 5.389 & 5.119 \\
\hline Equitability J & 0.7552 & 0.846 & 0.869 & 0.884 & 0.818 & 0.934 & 0.864 & 0.885 \\
\hline Fisher_alpha & 18.38 & 19.72 & 8.293 & 6.929 & 12.52 & 12.42 & 8.168 & 8.202 \\
\hline Berger-parker & 0.2459 & 0.206 & 0.149 & 0.0847 & 0.151 & 0.068 & 0.145 & 0.170 \\
\hline Chao-1 & 79.75 & 72 & 40 & 30 & 52.1 & 45 & 36 & 31 \\
\hline
\end{tabular}

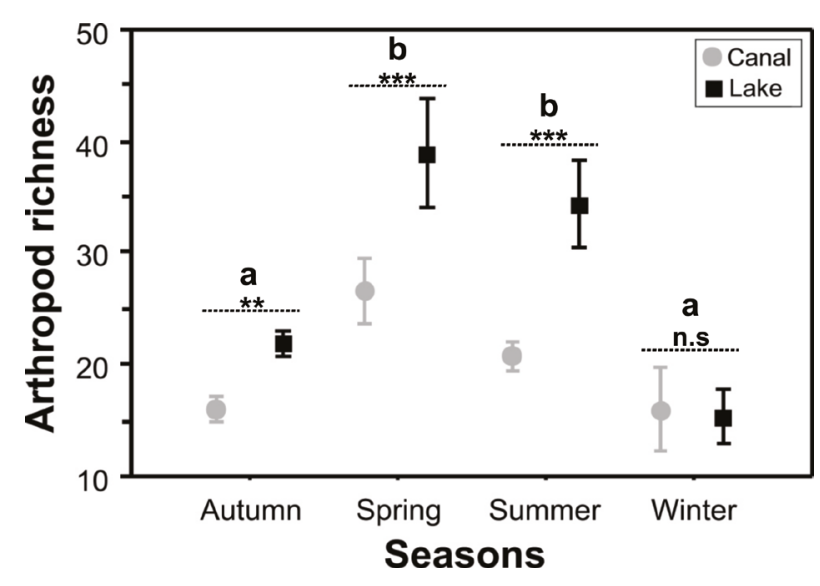

Fig. 2. Arthropod richness observed according to seasons and water bodies (canal and lake) studied. Different letters above error bars represent significant differences between stations. ${ }^{*} \mathrm{p}<0.05 ; * * \mathrm{p}<0.01 ; * * \mathrm{p}<0.001 ; \mathrm{n} . \mathrm{s}$, no significant difference.
The number of arthropod species differed between localities $\left(F_{1,16}=13.937, p<0.001\right)$ and between the studied seasons $\left(F_{3,16}=13.966, p<0.001\right)$. No significant interaction was found between these factors $\left(F_{3,16}=0.1003\right.$, $p<0.497)$. For both localities, no significant differences in species richness were observed between the Autumn and Winter seasons, as well as between Spring and Winter (Tukey Post Hoc-Test $>0.05$ ). All other stations were significantly different from each other (Tukey Post HocTest $<0.05$; Fig. 2).

The arthropod composition varied significantly according to the sampled sites $\left(F_{1,22}=3.9348, p<0.001\right)$ and according to the stations studied, for both Canal $\left(F_{3,8}\right.$ $=1.763, p=0.005)$ and Lake $\left(F_{3,8}=2.1702, p<0.001\right.$; Fig. 3). When considering the presence and absence of different arthropod species, the similarity observed between the fauna of the two localities was less than $20 \%$ (Fig. 4). The greatest similarity found between seasons was between summer and spring for both locations (about 
$50 \%$ similarity for Canal and $45 \%$ similarity for Lake; Fig. 4). Winter was being presented with the lowest similarity with the other (Fig. 4).

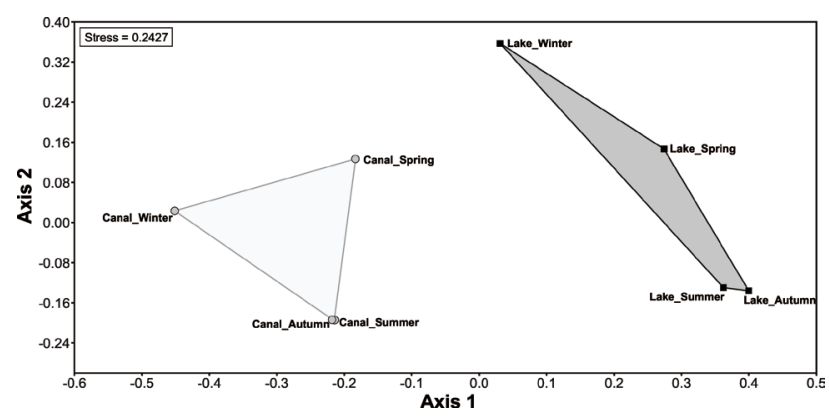

Fig. 3. Non-metric multidimensional scaling- NMDS (Bray-Curtis distance) of arthropod species composition according to different seasons and water bodies (canal and lake) studied. Stress $=0.2427$

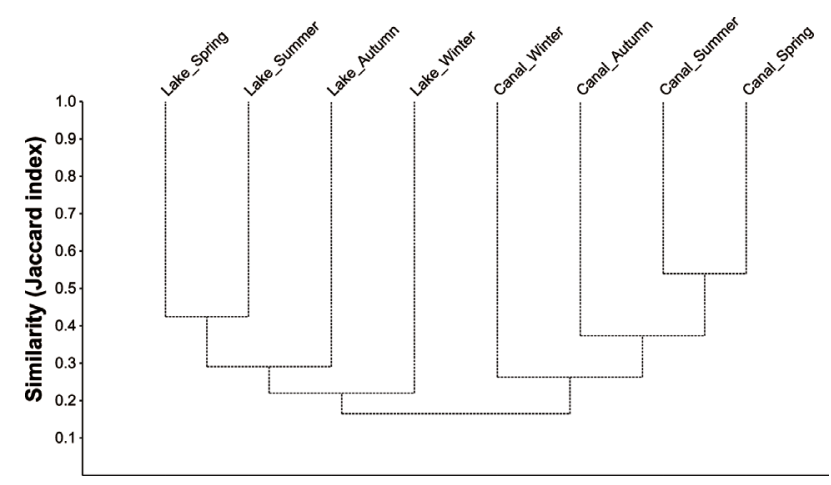

Fig. 4. Jaccard similarity dendrogram showing the similarity in arthropod fauna between the different seasons of the two water bodies (canal and lake) studied in Faisalabad, Punjab, Pakistan.

\section{DISCUSSION}

Biodiversity can be considered the whole variety of life, at all levels of the organization, regardless of the classification form (Colwell, 2009). Understanding this diversity has been the interest of several studies, both in aquatic and terrestrial environments (Foottit et al., 2009). Climatic variations are giant dilemma in our ecosystem; as seasonal extremes alter the diversity and abundance of arthropods in any territory. The common aspects that affect species diversity in terrestrial and aquatic ecosystem include habitat structure climate and biogeographical dynamics such as habitat area (Dossey, 2010). Wet territories have significant role in the strengthen of ecosystem, as they play eminent role in pollination, biological control of the pest etc. (Thompson and McLachlan, 2007). Arthropods are effective indicator of ecological variations because of their miscellaneous natural features and necessities (Hall and Castner, 2000; Clarke et al., 2008; Jaganmohan et al., 2012).

In this research, a total of 5867 specimens were recorded containing 8 orders, 72 families and 152 species (Table II). Similar study was done up to order, family and species by Majeed et al. (2019) and found that high population dynamics pertains alongside the water body. The role of arthropods fauna in the betterment vegetation alongside the wet territory needed to know due to the future conservation perspective of wetland fauna in biodiversity and ecology as well as in reverse vegetation also play important role in the enhancement of faunal diversity (Mahmoud and Shebl, 2014).

In our results, from Lake, maximum population was recorded for Tanytarsus spp. followed by Exitianus indicus. While for the Canal locality, maximum population was recorded for Musca domestica followed by Lucilia sericata. These species are in fact known to have high abundance of individuals (Basset, 2001). Romeny et al. (2002) documented that more diversity was recorded for Chironomid midges 51\% while other species were present in less number. Similar to the finding in other studies (Maguire, 2006; Vincent and Ring, 2009; Michael et al., 2007) diversity and abundance of species at order level was also examined and noted that Diptera had more influence on other recorded order (Romeny et al., 2002). It was found that Diptera presents to be more when compared to other species. The supremacy of Coleoptera and Lepidoptera in our study areas is showed by the extraordinarily maximum abundance of Ptiliidae, which prefer rotting wood, moist soil, and litter, are a prospective bioindicator of moist habitats (Sawada and Hirowatari, 2002; Hall, 2001; Sorensson, 2003). Ghosh-Harihar (2013) stated the diversity, richness and abundance of foliage arthropods. This trend has also been documented by Veenakumari and Prashanth (2009) who studied insect diversity in the mangroves of Andaman and Nicobar Islands of India who reported 50\% Lepidoptera; 5\% Orthoptera; 3\% Hymenoptera; 20\% Coleoptera; 15\% Hemiptera; 5\% Diptera; 2\% Thysanoptera.

Habitat structure is the amount, composition and arrangement of biotic and abiotic factors in any area, as an empirical driver of many ecological processes and regulate communities of many organisms in any ecosystem (Lovett et al., 2005). Seasonal changes and its effect on diversity was also noted significantly viz. from lake fields (spring, summer, autumn, winter) seasons abundance was noted $36.89 \%, 20.46 \%, 28.29 \%, 14.35 \%$, respectively. From canal fields, abundance was documented as for all seasons $34.87 \%, 20.12 \%, 29.41 \%, 15.59 \%$, respectively. Maguire 
(2006) studied the influence of abiotic factors on the species diversity and distribution in any habitat. Effects of temperature and resource variation on insect population dynamics was also observed by Johnson et al. (2016). In the present study a significant positive relationship was found between arthropod diversity and temperature. While humidity showed a significant negative relationship with diversity from lake and canal territory respectively. Arun and Vijayan (2004) estimated the relationship among ecological factors and the abundance of insects. Environmental factors such as rainfall, maximum temperature, minimum temperature, and relative humidity were monitored during the study. Among them, only the minimum temperature presented a significant negative correlation with the monthly variations in insect abundance.

The density of arthropods varied greatly over the growing season. Most arthropod groups were abundantly found in the spring-summer growing season (Rango, 2005). Liu et al. (2013) researched on arthropod distribution at microenvironments along vegetative areas in different seasons including shrubs of various plants and evaluated their activity periods as summer, spring and autumn. Tanaka and Tanaka (1982) estimated the changes in the arthropod's diversity due to rainfall and seasons and found that seasonal changes have significant correlation with the abundance of arthropod fauna.

In the present study, the lowest abundance values were found for winter. For species richness we found that, among seasons, spring has highest richness and evenness of species. Additionally, a marked variation in diversity indices was observed between the territories. These results are similar to previous studies that evaluated the diversity of arthropods in other localities. (Balakrishnan et al., 2014; Tewari et al., 2006). The diversity indices used in this study were complementary and showcased the high diversity and richness of insects in the ecosystem. Plant-insect interaction by way of phytophagy and mutualism may be responsible for this high species diversity as it has been shown that the diversity of vegetation in a habitat influences the diversity of insect species in such habitat (Alarape et al., 2015).

\section{CONCLUSIONS}

The pattern of arthropod diversity was investigated around two different wetlands and concluded that maximum abundance was recorded for lake fields as well as species number remained extraordinary as compared to Canal. The species richness of order Diptera was positively influenced by degree of habitat complexity. Not only the abundance, but species diversity was also positively correlated to the foliage vegetation structure. Seasonal alteration in the number of species and specimens was also noted during the whole trial. Hence, this study shows that seasons, climatic conditions, habitat structure have a significant impact on. Results might be beneficial in developing the strategy for natural biological control. It is suggested that the best fortification for the species examined in this study would be a network of water bodies sites, using different traditional and non-intensive methods. This can only be achieved by coordinated planning and conservation measures among sites.

\section{Supplementary material}

There is supplementary material associated with this article. Access the material online at: https://dx.doi. org/10.17582/journal.pjz/20200112020107

\section{Statement of conflict of interest}

The authors have declared no conflict of interest.

\section{REFERENCES}

Alarape, A.A., Omifolaji, J.K. and Mwansat, G.S., 2015. Butterfly species diversity and abundance in University of Ibadan Botanical Garden, Nigeria. Open J. Ecol., 5: 352-360. https://doi.org/10.4236/ oje.2015.58029

Amarasekare, P. and Coutinho, R., 2014. Effects of temperature on intraspecific competition in ectotherms. Am. Natural., 184: 50-65. https://doi. org/10.1086/677386

Amarasekare, P. and Sifuentes, R., 2012. Elucidating the temperature response of survivorship in insects. Funct. Ecol., 26: 959-968. https://doi.org/10.1111/ j.1365-2435.2012.02000.x

Anderson, M.J., 2001. A new method for non-parametric multivariate analysis of variance. Austral. Ecol., 26: 32-46. https://doi.org/10.1046/j.14429993.2001.01070.x

Arun, P.R. and Vijayan, V.S., 2004. Patterns in abundance and seasonality of insects in the Siruvani forest of Western Ghats, Nilgiri, Biosphere Reserve, Southern India. Sci. World J., 4: 381-392. https:// doi.org/10.1100/tsw.2004.33

Balakrishnan, S., Srinivasan, M. and Mohanraj, J., 2014. Diversity of some insect fauna in different coastal habitats of Tamil Nadu, southeast coast of India. J. Asia-Pacific Biodivers., 7: 408-414. https://doi. org/10.1016/j.japb.2014.10.010

Bale, J.S., Masters, G.J., Hodkinson, I.D., Awmack, C., Bezemer, T.M., Brown, V.K., Butterfield, J., Buse, A., Coulson, J.C., Farrar, J., Good, J.E.G., Harrington, R., Hartley, S., Jones, T.H., Lindroth, 
R.L., Press, M.C., Symrnioudis, I., Watt, A.D. and Whittaker, J.B., 2002. Herbivory in global climate change research: direct effects of rising temperature on insect herbivores. Glob. Change Biol., 8: 1-16. https://doi.org/10.1046/j.1365-2486.2002.00451.x

Basset, Y., 2001. Communities of insect herbivores foraging on saplings versus mature trees of Pourouma bicolor (Cecropiaceae) in Panama. Oecologia, 129: 253-260. https://doi.org/10.1007/ s004420100724

Berenbaum, M., Bernhardt, P., Buchmann, S., Calderone, N.W., Goldstein, P., Inouye, D.W., Kevan, P., Kremen, C., Medellin, R., Ricketts, T., Robinson, G.E., Snow, A.A., Swinton, S.M., Thien, L.B. and Thompson, F.C., 2006. Status of pollinators in North America. National Academies Press, Washington, DC.

Bommiredyy, P.L., Parajulee, M.N. and Porter, D.O., 2004. Influence of constant temperatures on life history of immature Lygus elisus (Hemiptera: Miridae). Environ. Ent., 33: 1549-1553. https://doi. org/10.1603/0046-225X-33.6.1549

Borror, D.J. and DeLong, D.M., 2005. An Introduction to the study of Insects. Columbus, Ohio.

Castillo, J., Jacas, J.A. and Pena, J.E., 2006. Effect of temperature on life history of Quadrastichus haitiensis (Hymenoptera: Eulophidae), an endo parasitoid of Diaprepes abbreviatus (Coleoptera: Curculionidae). Biol. Cont., 36: 189-196. https:// doi.org/10.1016/j.biocontrol.2005.09.023

Choate, B. and Drummond, F., 2011. Ants as biological control agents in agricultural cropping systems. Terr. Arthropod Rev., 4: 157-180. https://doi. org/10.1163/187498311X571979

Clarke, K.M., Fisher, B.L., and LeBuhn, G., 2008. The influence of urban park characteristics on ant (Hymenoptera, Formicidae) communities. Urban Ecosyst., 11: 317-334. https://doi.org/10.1007/ s11252-008-0065-8

Colwell, R.K., 2009. Biodiversity: Concepts, patterns, and measurement. In: The Princeton guide to ecology (eds. S.A. Levin, S.R. Carpenter, H. Charles, J. Godfray, A.P. Kinzig, M. Loreau, J.B. Losos, B. Walker and D.S. Wilcove). Princeton University Press. pp. 257-263. https://doi. org/10.1515/9781400833023.257

Crozier, L., 2004. Warmer winters drive butterfly range expansion by increasing survivorship. Ecology, 85: 231-241. https://doi.org/10.1890/02-0607

Dannon, E.A., Tamo, M., van Huis, A. and Dicke, M., 2010. Functional response and life history parameters of Apanteles taragamae, a larval parasitoid of Maruca vitrata. BioControl, 55: $363-$ 378. https://doi.org/10.1007/s10526-009-9263-4

De Conti, B., Bueno, V.H.P. and Sampaio, M.V., 2010. Reproduction and fertility life table of three aphid species (Macrosiphini) at different temperatures. Rev. Bras. Ent., 54: 654-660. https:// doi.org/10.1590/S0085-56262010000400018

Deutsch, C.A., Tewksbury, J.J., Huey, R.B., Sheldon, K.S., Ghalambor, C.K., Haak, D.C. and Martin, P.R., 2008. Impacts of climate warming on terrestrial ectotherms across latitude. Proc. natl. Acad.Sci., 105: 6668-6672. https://doi.org/10.1073/ pnas.0709472105

Dirzo, R., Young, H.S., Galetti, M., Ceballos, G., Isaac, N.J. and Collen, B., 2014. Defaunation in the Anthropocene. Science, 6195: 401-406. https://doi. org/10.1126/science. 1251817

Doblas-Miranda, E., Sánchez-Piñero, F. and GonzálezMegías, A., 2007. Soil macroinvertebrate fauna of a Mediterranean arid system: Composition and temporal changes in the assemblage. Soil Biol. Biochem., 39: 1916-1925. https://doi.org/10.1016/j. soilbio.2007.02.009

Dossey, A., 2010. Insects and their chemical weaponry: New potential for drug discovery. Nat. Prod. Rep., 27: 1737-1757. https://doi.org/10.1039/c005319h

Englund, G., Ohlund, G. and Hein, C., 2011. Temperature dependence of the functional response. Ecol. Lett., 14: 914-921. https://doi.org/10.1111/j.14610248.2011.01661.x

Foottit, R., Adler, G. and Holdridge, P., 2009. Insect biodiversity: Science and society. Blackwell Publishing, John Wiley \& Sons, Ltd., Publication. United States.

Forister, M.L., Emma, M.P. and Scott, H.B., 2019. Declines in insect abundance and diversity: We know enough to act now. Conserv. Sci. Pract., 1: e80. https://doi.org/10.1111/csp2.80

Ghosh-Harihar, M., 2013. Distribution and abundance of foliage-arthropods across elevational gradients in the east and west Himalayas. Ecol. Res., 28: 125130. https://doi.org/10.1007/s11284-012-1000-2

GOP, 2016. City District Government Faisalabad, Pakistan.

Hall, W.E., 2001. Ptiliidae. In: American beetles (eds. R.H. Arnett and M.C. Thomas). CRC Press, Boca Raton, Florida.

Hall, R.D. and Castner, J.L., 2000. Forensic entomology: The utility of arthropods in legal investigations. $3^{\text {rd }}$ Edition. CRC Press, Boca Raton, Florida.

Hillstrom, M.L. and Lindroth, R.L., 2008. Elevated atmospheric carbon dioxide and ozone alter forest 
insect abundance and community composition. Insect Conserv. Div., 1: 233-241. https://doi. org/10.1111/j.1752-4598.2008.00031.x

Hou, Y. and Weng, Z., 2010. Temperature-dependent development and life table parameters of Octodonta nipae (Coleoptera: Chrysomelidae). Environ. Ent., 39: 1676-1684. https://doi.org/10.1603/EN10015

Houghton, J.T., Ding, Y., Griggs, D.J., Noguer, M., van der Linden, P.J., Xiaosu, D., Maskell, K. and Johnson, C.A., 2001. Climate Change 2001: The scientific basis. Cambridge University Press, Cambridge.

Huang, Z., Ren, S. and Musa, P.D., 2008. Effects of temperature on development, survival, longevity, and fecundity of the Bemisia tabaci gennadius (Homoptera: Aleyrodidae) predator, Axinoscymnus cardilobus (Coleoptera: Coccinellidae). Biol. Cont., 46: 209-215. https://doi.org/10.1016/j. biocontrol.2008.04.004

Jaganmohan, M., Vailshery, L.S., Gopal, D. and Nagendra, H., 2012. Plant diversity and distribution in urban domestic gardens and apartments in Bangalore, India. Urban Ecosyst. 15: 911-925. https://doi.org/10.1007/s11252-012-0244-5

Jandricic, S.E., Wraight, S.P., Bennett, K.C. and Sanderson, J.P., 2010. Developmental times and life table statistics of Aulacorthum solani (Hemiptera: Aphididae) at six constant temperatures, with recommendations on the application of temperaturedependent development models. Environ. Ent., 39: 1631-1642. https://doi.org/10.1603/EN09351

Janzen, D.H., and Hallwachs, W., 2019. Perspective: Where might be many tropical insects? Biol. Conserv., 233: 102-108. https://doi.org/10.1016/j. biocon.2019.02.030

Johnson, C.A., Renato, M.C., Erin, B., Kimberly, E.D., Johanna, H., Britney, K., Alice, L., Jamie, L.S. and Priyanga, A., 2016. Effects of temperature and resource variation on insect population dynamics: the bordered plant bug as a case study. Funct. Ecol., 30: 1122-1131. https://doi.org/10.1111/13652435.12583

Kazakis, G., Ghosn, D., Vogiatzakis, I.N. and Papanastasis, V.P., 2006. Vascular plant diversity and climate change in the alpine zone of the Lefka Ori, Crete. Biodivers. Conserv., 16: 1603-1615. https://doi.org/10.1007/s10531-006-9021-1

Kingsolver, J., Woods, A., Buckley, L.B., Potter, L., MacLean, H. and Higgins, J., 2011. Complex life cycles and the responses of insects to climate change. Integr. Comp. Biol., 51: 719-732. https:// doi.org/10.1093/icb/icr015
Lang, B., Rall, B., Brose, Y. and Rall, B., 2011. Warming effects on consumption and intraspecific interference competition depend on predator metabolism. J. Anim. Ecol., 81: 516-523. https:// doi.org/10.1111/j.1365-2656.2011.01931.x

Liu, R., Zhu, F., Song, N., Yang, X. and Chai, Y., 2013. Seasonal distribution and diversity of ground arthropods in microhabitats following a shrub plantation age sequence in desertified steppe. PLoS One, 8: e77962. https://doi.org/10.1371/journal. pone.0077962

Lovett, G.M., Jones, C.G., Turner, M.G. and Weathers, K.C., 2005. Ecosystem function in heterogeneous landscapes. Springer, New York. https://doi. org/10.1007/b104357

Maguire, G.S., 2006. Territory quality, survival and reproductive success in southern emu-wrens Stipiturus malachurus. J. Avian Biol., 37: 579-593. https://doi.org/10.1111/j.2006.0908-8857.03757.x

Magurran, A.E., 1988. Ecological diversity and its management, Princeton University Press, New Jersey. https://doi.org/10.1007/978-94-015-7358-0

Mahmoud, M.F. and Shebl, M., 2014. Insect fauna of canola and phenology of the diamond back moth, Plutella xylostella L. (Lepidoptera: Plutellidae) as a key pest. J. Zool., 97: 125-132.

Majeed, W., Naureen, R., Qamar, S.R., Nargis, S., Raja, I.A., Kanwal, S. and Naseem, R., 2019. Diversity of foliage insects around different canal territories: A case study of Dingroo and Kamal Pur canal, Faisalabad, Pakistan. GSC Biol. Pharm. Sci., 6: 7-15. https://doi.org/10.30574/gscbps.2019.6.1.0161

Matadha, D. and Hamilton, G.C., 2004. Effect of temperature on development, fecundity, and life table parameters of Encarsia citrina Craw (Hymenoptera: Aphelinidae), a parasitoid of euonymus scale, Unaspis euonymi (Comstock), and Quadarspidiotus perniciosus (Comstock) (Homoptera: Diaspididae). Environ. Ent., 33: $1185-1191$. https://doi.org/10.1603/0046225X-33.5.1185

McMahon, S.M., Harrison, S.P., Armbruster, W.S., Bartlein, P.J., Beale, C.M., Edwards, M.E., Kattge, J., Midgeley, G., Morin, X. and Prentice, I.C., 2011. Improving assessment and modelling of climate change impacts on global terrestrial biodiversity. Trends Ecol. Evol., 26: 249-259. https://doi. org/10.1016/j.tree.2011.02.012

Medeiros, R.S., Ramalho, F.S., Zanuncio, J.C. and Serrao, J.E., 2003. Effect of temperature on life table parameters of Podisus nigrispinus (Heteroptera, Pentatomidae) fed with Alabama 
argillacea (Lepidoptera, Noctuidae) larvae. J. appl. Ent., 127: 209-213. https://doi.org/10.1046/j.14390418.2003.00728.x

Michael, J.W., Chadderton, W.L., Entrekin, S.A., Tank, J.L. and Harding, J.S., 2007. Distribution and dispersal of adult stream insects in a heterogeneous montane environment. Fund. appl. Limnol., 168: 127-135. https://doi.org/10.1127/18639135/2007/0168-0127

Morgan, D., Walters, K.F.A. and Aegerter, J.N., 2001. Effect of temperature and cultivar on the pea aphid, Acyrthosiphon pisum (Hemiptera: Aphididae) life history. Bull. Ent. Res., 91: 47-52.

Morrison, J.I. and Morecroft, M.D., 2006. Plant growth and climate change. New York, Wiley-Blackwell, pp. 232. https://doi.org/10.1002/9780470988695

Murdoch, W., Briggs, C.J. and Nisbet, R., 2003. Consumer-resource dynamics. Princeton University Press, Princeton New Jersey.

Nisbet, R., 1997. Delay-differential equations for structured populations. Chapman and Hall, New York. https://doi.org/10.1007/978-1-4615-597334

Nisbet, R.M. and Gurney, W., 1983. The systematic formulation of population-models for insects with dynamically varying instar duration. Theor. Popul. Biol., 23: 114-135. https://doi.org/10.1016/00405809(83)90008-4

Nishikawa, H., Shimada, T. and Nakahira, K., 2010. Thermal effect on the development and reproduction of an indigenous mirid bug, Pilophorus typicus distant (Heteroptera: Miridae), a potential biological control agent in Japan. Appl. Ent. Zool., 45: 313-318. https://doi.org/10.1303/ aez.2010.313

Oksanen, J., Kindt, R., Legendre, P., Minchin, P.R., O’Hara, R.B., Simpson, G.L., Solymos, P., Stevens, M.H.H. and Wagner, H. 2015. The vegan package. $\mathrm{R}$ package version 2.3-4. Available at: https:// cran.r-project.org/package= $=$ vegan.

Parajulee, M., 2006. Influence of constant temperatures on life history parameters of the cotton aphid, Aphis gossypii, infesting cotton. Environ. Ent., 36: 666-672. https://doi.org/10.1093/ee/36.4.666

$\mathrm{R}$ Development Core Team, 2018. R: A language and environment for statistical computing. $\mathrm{R}$ Foundation for Statistical Computing, Vienna, Austria. Available at: http://www.Rproject.org/

Rafi, M.A., Irshad, M. and Inyatullah, M., 2005. Predatory ladybird beetles of Pakistan. National Agriculture Research Center, Islamabad.

Ragland, G.J. and Kingsolver, J.G., 2008. The effect of fluctuating temperatures on ectotherm life-history traits: comparisons among geographic populations of Wyeomyia smithii. Evol. Ecol. Res., 10: 29-44.

Rango, J.J., 2005. Arthropod communities on creosote bush (Larrea tridentata) in desert patches of varying degrees of urbanization. Biodivers. Conserv., 14: 2185-2206. https://doi.org/10.1007/s10531-0044669-x

Romeny, J., Lynch, S., Bunn, E. and Catterall, C.P., 2002. Adult aquatic insects: Potential contributors to riparian food webs in Australia's wet-dry tropics. Aust. Ecol., 27: 515-526. https://doi.org/10.1046/ j.1442-9993.2002.01208.x

Root, T.L., Price, J.T., Hall, K.R., Schneider, S.H., Rosenzweig, C. and Pounds, J.A., 2003. Fingerprints of global warming on wild animals and plants. Nature, 421: 57-60. https://doi.org/10.1038/ nature 01333

Sánchez-Bayo, F. and Wyckhuys, K.A.G., 2019. Worldwide decline of the entomofauna: A review of its drivers. Biol. Conserv., 232: 8-27. https://doi. org/10.1016/j.biocon.2019.01.020

Savage, V.M., Gillooly, J.F., Brown, J.H., West, G.B. and Charnov, E.L., 2004. Effects of body size and temperature on population growth. Am. Nat., 163: 429-441. https://doi.org/10.1086/381872

Sawada, Y. and Hirowatari, T., 2002. A revision of the genus Acrotrichis Motschulsky (Coleoptera: Ptiliidae) in Japan. Entomol. Sci., 5: 77-101.

Shannon, C.E., 1948. A mathematical theory of communication Bell. Syst. Tech. J., 27: 379423. https://doi.org/10.1002/j.1538-7305.1948. tb01338.x

Sheldon, K.S., Yang, S. and Tewksbury, J.J., 2013. Climate change and community disassembly impacts of warming on tropical and temperate montane community structure. Ecol. Lett., 14: 1191-1200. https://doi.org/10.1111/j.14610248.2011.01689.x

Sorensson, M., 2003. New records of feather wing beetles (Coleoptera: Ptiliidae) in North America. Coleopt. Bull., 14: 1191-1200.

Tanaka, L.K. and Tanaka, S.K., 1982. Rainfall and seasonal changes in arthropod abundance on a tropical oceanic Island. Biotropica, 14: 114-123. https://doi.org/10.2307/2387740

Tewari, M., Poonam, B.D. and Kaushal, R., 2006. Diversity of terrestrial insects in a cultivated land of Tarai region of Kumaun, Uttaranchal. Entomology, 31: 207-216.

Thompson, B. and McLachlan, S. 2007. The effects of urbanization on ant communities and myrmecochory 
in Manitoba, Canada. Urban Ecosyst., 10: 43-52. https://doi.org/10.1007/s11252-006-0013-4

Thuiller, W., Lavorel, S., Araujo, M.B., Sykes, M.T. and Prentice, C., 2005. Climate change threats to plant diversity in Europe. Proc. natl. Acad. Sci., 102: 82458250. https://doi.org/10.1073/pnas.0409902102

Triplehorn, C.A. and Johnson, N.F., 2005. Borror and DeLong's introduction to the study of Insects. $7^{\text {th }}$ Edition, Thompson-Brooks/Cole, Belmont, CA.

Ulmer, B.J., Jacas, J.A., Pena, J.E., Duncan, R.E. and Castillo, J., 2006. Effect of temperature on life history of Aprostocetus vaquitarum (hymenoptera: Eulophidae), an egg parasitoid of Diaprepes abbreviatus (coleoptera: Curculionidae). Biol. Cont., 39: 19-25. https://doi.org/10.1016/j. biocontrol.2006.03.002

Urbaneja, A., Llacer, E., Garrido, A. and Jacas, J.A., 2001. Effect of temperature on the life history of Cirrospilus sp. near lyncus (Hymenoptera: Eulophidae), a parasitoid of Phyllocnistis citrella (Lepidoptera: Gracillariidae). Biol. Cont., 21: 293-
299. https://doi.org/10.1006/bcon.2001.0944

Veenakumari, K. and Mohanraj, P., 2009. A note on the entomofauna of mangrove associates in the Andaman Islands (Indian Ocean: India). J. Nat. Hist., 43: 1314. https://doi.org/10.1080/00222930802610550

Vincent, H.R. and Ring, T.C., 2009. Encyclopedia of insects. Academic Press, New York.

Wagner, D.L., 2018. Trends in biodiversity: Insects. Elsevier, Oxford, England. pp. 131-143. https://doi. org/10.1016/B978-0-12-809665-9.09819-0

Whitford, W.G., 2000. Keystone arthropods as webmasters in desert ecosystems. In: Invertebrates as webmasters in ecosystems (eds. D.C. Coleman and P.F. Hendrix). CABI Publishing, London. pp. 2542. https://doi.org/10.1079/9780851993942.0025

Zamani, A., Talebi, A., Fathipour, Y. and Baniameri, V., 2006. Effect of temperature on biology and population growth parameters of Aphis gossypii Glover (Homoptera: Aphididae) on greenhouse cucumber. J. Appl. Ent., 130: 453-460. https://doi. org/10.1111/j.1439-0418.2006.01088.x 